\title{
Integrated Disease Management of Rhizoctonia Root Rot of Chilli (Capsicum annum L.) Incited by Rhizoctonia solani Kuhn in vivo
}

\author{
Sunaina Varma ${ }^{1 *}$, Data Ram Kumhar ${ }^{2}$, Ashok Kumar Meena ${ }^{2}$, \\ Priyanka $^{3}$ and Balvinder ${ }^{4}$
}

${ }^{1}$ Department of Plant Pathology, College of Agriculture, Swami Keshwanand Rajasthan

Agricultural University, Bikaner - 334 006, Rajasthan, India

${ }^{2}$ College of Agriculture, ${ }^{3}$ Department of Plant Pathology, ${ }^{4}$ Department of Entomology,

College of Agriculture, Swami Keshwanand Rajasthan Agricultural University, Bikaner,

Rajasthan, India

*Corresponding author

K e y w o r d s
Chemical measures,
$\begin{aligned} & \text { Fungitoxicants, } \\ & \text { Rhizoctonia solani } \\ & \text { Kuhn, Trichoderma } \\ & \text { harzianum, } \\ & \text { Pseudomonas } \\ & \text { fluorescence }\end{aligned}$
Article Info
Accepted:
12 March 2020
Available Online:
10 April 2020

\section{Keywords}

Chemical measures,

Fungitoxicants,

Rhizoctonia solani

harzianum

Pseudomonas

Article Info

Accepted:

12 March 2020

10 April 2020

\section{A B S T R A C T}

Study carried out of this disease over a period of time revealed that Rhizoctonia solani Kuhn affects the yield severely whenever it occurs at any stage of the crop. In spite chemical measures like copper oxy chloride is recommended based on the previous studies on Rhizoctonia spp., the new fungicides need to be evaluated to find out the effective and economic fungitoxicants with which the disease can be controlled. Keeping in mind the seriousness of the disease, it was planned to elucidate the biocontrol and fungicidal capacity as soil and seed treatment against the pathogen, $R$. solani and also to evolve suitable management strategies to prevent the losses incurred due to Rhizoctonia root rot of chilli. In the present field experiment, soil application with Trichoderma harzianum in combination with seedling dip treatment with Tebuconazole 2DS was most effective in minimizing the Rhizoctonia root rot incidence $(8.55 \%)$ followed by soil application of Pseudomonas fluorescence in combination with seedling dip treatment with (11.74\%) as compared to other treatments. Further the treatment having the seedling dip treatment with Tebuconazole 2DS in combination of soil drenching of Tebuconazole 50\% + Trifloxystrobin $20 \%$ WG was also effective shows that this new fungicide is also effective against $R$. solani. All the treatments in the field trial were found significantly increased the yield as compared to control. Highest yield of green chilli (145.27 q/ha) was obtained in the treatment of soil application of T. harzianum @ $10 \mathrm{~kg} / \mathrm{ha}$ in combination with seedling dip treatment of Tebuconazole 2DS.

\section{Introduction}

Chilli (Capsicum annum L.) is one of the most important commercial crop of India belongs to the Solanaceae family mainly cultivated for its green fruits as vegetable and dry chilli as spice purpose. Chilli is commercially important for two qualities, i.e., 
its red colour is due to the pigment capsanthin and its biting pungency is due to capsaicin. The chilli crop is suffered by various diseases caused by fungi, bacteria and viruses at different stages of crop. Among the major diseases of chilli, root rot of chilli caused by $R$. solani has attained the economic importance. The disease is difficult to manage as the pathogen has long saprophytic survival ability in soil. It can cause up to 33.2 percent disease incidence of the seedling in greenhouse condition and in main field 40.2 percent (Rini and Sulochana, 2006). R. solani is a seed and soil borne pathogens. Malhotra et al., (2011) studied that Rhizoctonia solani, which causes damping-off disease of seedlings as well as root and stem rot in young transplants, is a major soil-borne pathogen of chilli (Capsicum annum L.).

In the year 2001 root rot of chilli was first time reported from Rajasthan near Jaipur chilli growing areas, where the sever mortality of chilli plants during March-April was observed (Kalmesh and Gurjar, 2001). Harikrishnan and Yang, (2004) studied that diseased plants often produce an abundance of secondary roots above the rotted tap root, but wilting, stunted growth and death of plants scattered throughout the field are the most noticeable symptoms of Rhizoctonia root rot. Once a plant is infected, vigour is greatly reduced and production is poor and the resulted poor stand that is mistakenly ascribed to poor seed quality or seed maggots rather than to the presence of diseases.

Among the fungal diseases, root rot complex of chilli is a serious infestation. In standing plants, yellowing and wilting are usually preceded by light to dark brown lesion on the stem adjacent to the ground followed by drooping and wilting of infected leaves and gradual wilting of infected leaves and gradual wilting of the whole plant. Mature plants dry suddenly. Seedlings affected by this infestation die soon after germination (Varma et al., 2019). Keeping in mind the seriousness of the disease, it was planned to elucidate the biocontrol and fungicidal capacity as soil and seed treatment against the pathogen, $R$. solani and also to evolve suitable management strategies to prevent the losses incurred due to Rhizoctonia root rot of chilli.

\section{Materials and Methods}

The infected samples of Rhizoctonia solani Kuhn incitant of root rot were collected from chilli diseased fields of different districts of Rajasthan, viz. Sri Ganganager, Hanumangarh, Bikaner (Agricultural Research Station and farmer's field) and Jaipur. The samples collected from diseased plants were used for isolation. The roots were thoroughly washed with tap water to remove soil. Small pieces of about $0.5 \mathrm{~cm}$ length were surface sterilized with 0.1 per cent mercuric chloride solution for 2 minutes, three washings with sterilized distilled water were given, placed on PDA slant in a laminar flow and incubated at $28 \pm 1^{\circ} \mathrm{C}$ temperature for growth for seven days. To maintain the pure culture of Rhizoctonia solani, single hyphal tip isolation technique was adopted.

The single piece of hypha was demarcated under low power of microscope (10X) and cut with the help of mechanical cutter. Individual piece of hypha was transformed on PDA slants with the help of an inoculating needle. The inoculated slants were kept in Biological Oxygen Device Incubator for growth at $28 \pm$ $1^{0} \mathrm{C}$ for 7 days. Thus, the purified cultures of five isolates from diseased chilli field from Rajasthan were maintained by periodical transfers on PDA slants and used for further studies.

To incite the disease, sand maize medium was prepared. The culture of Rhizoctonia solani was multiplied on sand maize flour medium 
(1:1). $2.1 \mathrm{~kg}$ of maize flour was mixed in 4.33 $\mathrm{kg}$ of sand and was filled in the conical flasks of $250 \mathrm{ml}$ capacity (50 g/flask) and sterilized in autoclave at $15 \mathrm{Lbs}$ for $30 \mathrm{~min}$. Then, the flasks were inoculated aseptically with pure culture of Rhizoctonia solani. $5 \mathrm{~mm}$ mycelial disc of the test pathogen are transferred into the conical flask and incubated at room temperature for 15 days. After 15 days of incubation, the inoculum was taken out from the flask and mixed thoroughly with sterilized sand plus soil mixture (1:1) at $100 \mathrm{~g}$ inoculums per $\mathrm{kg}$ soil. This mixture was used for making sick plot.

In the laboratory antagonistic activity of three sp. of Trichoderma, one species of Bacillus and one species of Pseudomonas were tested and on the basis of best antagonist, we selected most powerful antagonist Trichoderma harzianum and Pseudomonas for field experiment.

In this experiment two bioagents viz., Trichoderma harzianum, and Pseudomonas fluorescens were used as soil application and seedling dip treatment. For soil application, talc based formulation of bioagents @ $10 \mathrm{~kg}$ $\mathrm{ha}^{-1}$ prepared in the laboratory were used. For seedling dip treatment, bioagent were used @ $10 \mathrm{~g} \mathrm{lt}^{-1}$ talc based formulation of bioagents dipped for one and half hour, removed the seedling from solution and air dried in shed before use.

In order to study the effect of two biocontrol agents Trichoderma harzianum and Pseudomonas fluorescens were tested individually as seedling dip treatment as well as soil application alone and further the combination of seedling dip treatment and soil application were also tested. The combination of seedling dips treatment with Tebuconazole 2DS @ $1.5 \mathrm{~g} / \mathrm{lt}$ and soil application of bioagents were also tested in field condition.

For fungicidal seedling treatment, seedlings were dipped in Tebuconazole 2 DS @ 1.5g/lt water solution for one and half hour. For soil drenching, combination of fungicides Tebuconazole 50\% + Trifloxystrobin 20\% WG (Nativo) @ 1 ml/lt of water was used. All the bioagents and fungicide which were used in vitro conditions also tested under in vivo condition. Treatments like soil drenching were applied immediately after the appearance of root rot in the field (Table 1). The observations of Rhizoctonia root rot incidence were recorded periodically and per cent disease incidence was calculated. Disease incidence was worked out by the following formula:

\begin{tabular}{|c|c|}
\hline \multirow{2}{*}{ Percent disease incidence $=$} & Total no. of infected plant \\
\hline & Total no. of plant observed \\
\hline \multirow{2}{*}{ Percent disease control $=$} & $\begin{array}{l}\text { Disease intensity in control-Disease } \\
\text { intensity in treatment }\end{array}$ \\
\hline & Disease intensity in control \\
\hline
\end{tabular}

Yied of green chilli was recorded from each plot and analyzed the data. In the field experiment, different treatments individually as well as in combination were tested for the management of Rhizoctonia root rot disease in chilli. Following treatment were tested in 
field studies. The field experiment was laid out during kharif 2016 at experimental nursery farm, College of Agriculture, Swami Keshwanand Rajasthan Agricultural University, Bikaner. The chilli seedlings were transplanted on $8^{\text {th }}$ October, 2016 keeping plot size $2.4 \times 2.7 \mathrm{~m}^{2}$ with $60 \times 45 \mathrm{~cm}$ row to row and plant to plant distance following Randomized Block Design with three replications.

The pure cultures of $T$. harzianum, $P$. fluorescens and Trichoderma viride were obtained from the Department of Plant Pathology, COA, SKRAU, Bikaner and were mass multiplied in the laboratory. The final carrier based product was applied in soil 7 days after sowing at the recommended rate.

\section{Results and Discussion}

In the present field experiment as given in table 2, soil application with $T$. harzianum in combination with seedling dip treatment with Tebuconazole 2DS was most effective in minimizing the Rhizoctonia root rot incidence $(8.55 \%)$ followed by soil application of $P$. fluorescens in combination with seedling dip treatment with $(11.74 \%)$ as compared to other treatments.

It is evident from the findings that seedling dip treatment with fungicides in combination of soil application of $T$. harzianum or $P$. fluorescens is most effective for managing Rhizoctonia root rot disease in chilli. This is due to the fact that in an early stage, fungicide inhibits the $R$. solani and later on bioagents multiply in the field and effectively check the $R$. solani. Further the treatment having the seedling dip treatment with Tebuconazole 2DS in combination of soil drenching of Tebuconazole 50\% + Trifloxystrobin 20\% WG was also effective shows that this new fungicide is also effective against $R$. solani.
In the present studies it was observed that seed treatment with $T$. harzianum or $P$. fluorescens alone was more effective as compared to soil application of T. harzianum or P. fluorescens. It indicates that the seed treatment is more effective against $R$. solani as compared to soil application. The efficacy of bioagent increased when combination of seedling dip treatment and soil application were used in field. The bioagent act against $R$. solani from seedling to maturity stage due to the fact that the soil becomes rich by the bioagents that protect the crop against $R$. solani at all stage of growth.

The integration of BCAs with chemical fungicide Tebuconazole 2DS resulted lesser Rhizoctonia root rot incidence compared to the individual treatment of BCAs and fungicide. The present findings is supported by earlier works wherein integration of biocontrol agents with fungicides gave significantly higher disease control in several crops than that obtained either by bio-control agent or by fungicide alone (Rather et al., 2012; Sawant and Mukhopadyay, 1990; Dubey, 1997; Nagamani et al., 2014).

The integration of seedling dip treatment of Tebuconazole 2DS and soil application of bioagents i.e. T. harzianum and P. fluorescens was highly effective for the management of Rhizoctonia root rot. Seedling dip treatment of bioagents was more effective than soil application for all the evaluated parameters. Dubey et al., (2013) also recorded similar findings. Seedling dip treatment of fungicide was more effective than seedling dip treatment of bioagents. This finding is supported by Patel et al., (2014). Treatment of seedling dip of bioagents i.e. T. harzianum and $P$. fluorescens significantly control the per cent disease incidence. This findings supported by Kumar et al., (2012); Dewangan et al., (2014) in which, Kumar et al., (2012) reported that biological control of soil borne 
plant pathogens can be achieved successfully by seed coating, furrow application and root dip of seedlings with antagonists. Application of $P$. fluorescens and Trichoderma spp. are such example of biocontrol agents with plant growth promoting ability coupled with antagonistic effect in phytopathogens (Dewangan et al., 2014).

Seedling dip treatment of bioagent i.e. T. harzianum and $P$. fluorescens had minimum Rhizoctonia root rot incidence followed by soil application of $T$. harzianum and $P$. fluorescens as compared to control. This finding is in agreement with Rehman et al., (2013); Manoranjitham et al., (1999); Bunker and Mathur, (2001); Faruk et al., (2002) and Champawat and Sharma, (2003). The seedling dip treatment of chemical fungicide
Tebuconazole 2DS was more effective in controlling disease incidence as compared to seedling dip treatment of bioagents i.e T. harzianum and $P$. fluorescens. This finding supported by Ngullie and Daiho, (2013).

Highest yield of green chilli (145.27 q/ha) was also obtained in the treatment of soil application of T. harzianum @ $10 \mathrm{~kg} / \mathrm{ha}$ in combination with seedling dip treatment of Tebuconazole 2DS remained superior to all other treatments. The bioagent in combination with Tebuconazole 2DS inhanced the yield more effectively as compared to sole application of bioagent. The results obtained with this experiment confirm the earlier reports by Rather et al., (2012); Ngullie and Daiho (2013).

Table.1 Treatment details

\begin{tabular}{|c|c|c|}
\hline S. No. & Treatment & Dose \\
\hline $\mathbf{T}_{1}$ & T. harzianum & ST @ $10 \mathrm{~g} \mathrm{Lt}^{-1}$ \\
\hline $\mathbf{T}_{2}$ & P. fluorescens & $\mathrm{ST} @ 10 \mathrm{~g} \mathrm{Lt}^{-1}$ \\
\hline $\mathbf{T}_{\mathbf{3}}$ & Tebuconazole 2DS & $\mathrm{ST} @ 1.5 \mathrm{~g} \mathrm{Lt}^{-1}$ \\
\hline $\mathbf{T}_{4}$ & T. harzianum & SA@10 kg ha ${ }^{-1}$ \\
\hline $\mathbf{T}_{\mathbf{5}}$ & P. fluorescens & SA @ $10 \mathrm{~kg} \mathrm{ha}^{-1}$ \\
\hline $\mathbf{T}_{6}$ & $\begin{array}{l}\text { Tebuconazole } 50 \%+\text { Trifloxystrobin } 20 \% \\
\text { WG }\end{array}$ & Soil drenching $1 \mathrm{ml} \mathrm{Lt}^{-1}$ \\
\hline $\mathbf{T}_{7}$ & T. harzianum & ST@10 $\mathrm{gtt}^{-1}+\mathrm{SA} @ 10 \mathrm{~kg} \mathrm{ha}^{-1}$ \\
\hline $\mathbf{T}_{\mathbf{8}}$ & P. fluorescens & ST@10 $\mathrm{kt}^{-1}+\mathrm{SA} @ 10 \mathrm{~kg} \mathrm{ha}^{-1}$ \\
\hline $\mathbf{T}_{9}$ & Tebuconazole $2 \mathrm{DS}+\mathrm{T}_{6}$ & ST@ $1.5 \mathrm{~g} \mathrm{Lt}^{-1}+$ Soil drenching $1 \mathrm{ml} \mathrm{Lt}^{-1}$ \\
\hline $\mathbf{T}_{\mathbf{1 0}}$ & Tebuconazole 2DS $+T$. harzianum & ST $@ 1.5 \mathrm{~g} \mathrm{Lt}^{-1}+\mathrm{SA} @ 10 \mathrm{~kg} \mathrm{ha}^{-1}$ \\
\hline $\mathbf{T}_{11}$ & Tebuconazole 2DS $+P$. fluorescens & ST@1.5 $\mathrm{g} \mathrm{Lt}^{-1}+\mathrm{SA} @ 10 \mathrm{~kg} \mathrm{ha}^{-1}$ \\
\hline $\mathbf{T}_{12}$ & Control & \\
\hline
\end{tabular}


Table.2

\begin{tabular}{|c|c|c|c|c|c|}
\hline $\begin{array}{c}\text { Treatment } \\
\text { No. }\end{array}$ & Treatment & Dose & $\begin{array}{l}\text { Per cent } \\
\text { root rot } \\
\text { incidence }\end{array}$ & $\begin{array}{l}\text { Per cent } \\
\text { inhibition }\end{array}$ & $\begin{array}{l}\text { Yield } \\
\left(\mathbf{q} \text { ha }^{-1}\right)\end{array}$ \\
\hline $\mathbf{T}_{1}$ & T. harzianum & ST @ $10 \mathrm{~g} \mathrm{Lt}^{-1}$ & $\begin{array}{c}23.41 \\
(28.91)^{*}\end{array}$ & 51.73 & 90.33 \\
\hline $\mathbf{T}_{2}$ & P. fluorescens & $\mathrm{ST} @ 10 \mathrm{~g} \mathrm{Lt}^{-1}$ & $\begin{array}{c}25.31 \\
(30.18)\end{array}$ & 47.82 & 85.00 \\
\hline $\mathbf{T}_{\mathbf{3}}$ & Tebuconazole 2DS & ST@1.5 $\mathrm{g} \mathrm{Lt}^{-1}$ & $\begin{array}{c}21.60 \\
(27.52)\end{array}$ & 55.46 & 100.50 \\
\hline $\mathbf{T}_{4}$ & T. harzianum & SA@10 kg ha ${ }^{-1}$ & $\begin{array}{c}28.46 \\
(31.77)\end{array}$ & 41.32 & 80.00 \\
\hline $\mathbf{T}_{5}$ & P. fluorescens & SA@10 kg ha & $\begin{array}{c}31.28 \\
(33.74)\end{array}$ & 35.51 & 75.13 \\
\hline $\mathbf{T}_{6}$ & $\begin{array}{l}\text { Tebuconazole } 50 \% \\
\text { +Trifloxystrobin } 20 \% \\
\text { WG }\end{array}$ & $\begin{array}{c}\text { Soil drenching } 1 \\
\mathrm{ml} \mathrm{Lt}^{-1}\end{array}$ & $\begin{array}{l}16.89 \\
(24.22)\end{array}$ & 65.18 & 115.00 \\
\hline $\mathbf{T}_{7}$ & T. harzianum & $\begin{array}{l}\text { ST @ } 10 \mathrm{~g} \mathrm{Lt}^{-1}+ \\
\text { SA @ } 10 \mathrm{~kg} \mathrm{ha}^{-1}\end{array}$ & $\begin{array}{c}15.79 \\
(23.40)\end{array}$ & 67.44 & 120.17 \\
\hline $\mathbf{T}_{8}$ & P. fluorescens & $\begin{array}{l}\mathrm{ST} @ 10 \mathrm{~g} \mathrm{Lt}^{-1}{ }^{-1} \\
\mathrm{SA} @ 10 \mathrm{~kg} \mathrm{ha}^{-1}\end{array}$ & $\begin{array}{l}19.23 \\
(25.99)\end{array}$ & 60.35 & 112.33 \\
\hline $\mathbf{T}_{9}$ & $\begin{array}{l}\text { Tebuconazole 2DS + } \\
\text { Tebuconazole } 50 \% \\
+ \text { +Trifloxystrobin } 20 \% \\
\text { WG }\end{array}$ & $\begin{array}{l}\text { ST@ } 1.5 \mathrm{~g} \mathrm{Lt}^{-1}+ \\
\text { Soil drenching } 1 \\
\mathrm{ml} \mathrm{Lt}^{-1}\end{array}$ & $\begin{array}{c}12.61 \\
(20.70)\end{array}$ & 74.01 & 138.33 \\
\hline $\mathbf{T}_{10}$ & $\begin{array}{l}\text { Tebuconazole } 2 \mathrm{DS}+T \text {. } \\
\text { harzianum }\end{array}$ & $\begin{array}{c}\text { ST @ } 1.5 \mathrm{~g} \mathrm{Lt}^{-1}+ \\
\mathrm{SA} \\
@ 10 \mathrm{~kg} \mathrm{ha}^{-1}\end{array}$ & $\begin{array}{c}8.55 \\
(16.91)\end{array}$ & 82.36 & 145.27 \\
\hline $\mathbf{T}_{11}$ & $\begin{array}{l}\text { Tebuconazole } 2 \mathrm{DS}+P \text {. } \\
\text { fluorescens }\end{array}$ & $\begin{array}{l}\text { ST@1.5 } \mathrm{g} \mathrm{Lt}^{-1}{ }^{+} \\
\text {SA @ } 10 \mathrm{~kg} \mathrm{ha}^{-1}\end{array}$ & $\begin{array}{c}11.74 \\
(19.99)\end{array}$ & 75.80 & 139.00 \\
\hline \multirow[t]{4}{*}{$\mathbf{T}_{12}$} & Control & & $\begin{array}{c}48.50 \\
(44.12)\end{array}$ & $-(00)$ & 65.00 \\
\hline & $\mathrm{S} \mathrm{Em}( \pm)$ & & 2.28 & & 9.36 \\
\hline & $\mathrm{CD}(\mathrm{P}=0.05)$ & & 6.73 & & 27.63 \\
\hline & $\mathrm{CV}(\%)$ & & 14.49 & & 15.43 \\
\hline
\end{tabular}

*values in parenthesis are angular transformed

$\mathrm{ST}=$ Seedling dip treatment $\quad \mathrm{SA}=$ Soil application 
Conclusively, the soil application of bioagents in combination with seedling dip treatment with Tebuconazole 2DS reduced the disease incidence more effectively as compared to sole application of bioagent as seedling dip or soil application.

The present findings indicate the possibility of using integration of biocontrol agents likewise Trichoderma and Pseudomonas fluorescens and chemical fungicide likewise Tebuconazole 2DS for the management of Rhizoctonia root rot disease on chilli. However, this should be further evaluated by comparing the present isolates with other cultures and fungicide.

\section{References}

Bunker, R.N. and Mathur, K. 2001. Antagonism of Local Bio control agents to Rhizoctonia solani Inciting Dry rootrot of Chilli. J. Mycol. Plant Pathol. 31(1): 50-53.

Champawat, R.S. And Sharma, R.S. 2003. Integrated Management Of Nursery Disease in Brinjal, Chilli, Cabbage and Onion. J. Mycol. Plant Pathol. 33(2): 290-291.

Dewangan, P.K., Koma, B., Baghel, S., Khare, N. and Singh, H. K. 2014. Characterization of Pseudomonas fluorescens in Different Media and its Antagonistic Effect on Phytopathogenic Fungi. The Bioscan. 9 (1): 317-321.

Dubey, S. C. 1997. Biological Control of Web blight of Groundnut Caused by Thanatephorus cucumeris. Golden Jubilee international Conference of IPS at IARI. pp194.

Faruk, M.I., Rahman, M.L. and Bari, M.A. 2002. Management of Seedling Disease of Cabbage through Trichoderma harzianum Amendment in Seedbed. Bangladesh J. Plant Pathol. 18(12):49-53.
Harikrishnan, R. and Yang. X.B. 2004. Recovery of Anastomosis groups of Rhizoctonia solani from Different Latitudinal Positions and influence of Temperatures on their growth and survival. Plant Dis. 88: 817-823.

Kalmesh M, Gurjar RBS. 2001. Sclerotium rolfsii - A new Threat to chilli in Rajasthan. J Mycol Plant Pathol. 2001; 31(2):261.

Kumar, J.V., Ramya, S.R., Nambisan, B., Mohandas, C. 2012. Improvement of Antimicrobial Activity of Compounds Produced by Bacillus sp. associated with a Rhabditid sp. (Entimopathogenic nematode) by Changing Carbon and Nitrogen sources in fermented media. $J$. Microbiol. Biotechnol. Food Sci. 1: 1424-1438.

Malhotra, A., Agarwal, T., and Trivedi, P. C. 2011. In vitro efficacy of Various Fungal and Bacterial Antagonists against Rhizoctonia solani, Causal agent of Damping off disease in Capasicum annum L. International J. Pharm. BioSci. 3(2):288-292.

Manoranjitham, S.K., Prakassam, V., Rajappan, K. 1999. Effect of Antagonists on Pythium aphanidermatum (Edson) Fitz and the growth of Chilli seedlings. J. Biol. Control. 13(1-2):101-106.

Nagamani, P., Viswanath, K. and Kiran babu, T. 2014. Management of Dry root rot Caused by Rhizoctonia bataticola (Taub.) Butler in chickpea. Current Biotica. 5(3): 364-369.

Ngullie, M. and Daiho, L. 2013 .Efficacy of bio control agents in controlling Rhizoctonia solani on naga king chilli (Capsicum chinense Jacq.). J. of Experi. Biol. Agric.Sci. 1(3):198-201.

Patel, M.D., Lal, A.A. and Singh, P.P. 2014. Efficacy of Certain Bio agents and Fngicides against Root rot of Chilli (Capsicum annum L.). Phytopathology . 
9(3): 1273-1277.

Rahman, M.M., Ali, M.E., Khan, A.A., Akanda, A.M., Uddin, M.D., Hashim, U. and AbdHamid, S.B. 2013. Isolation, Characterization, and Identification of Biological Control Agent for Potato Soft rot in Bangladesh. The Scientific World Journal. 6: 1-6.

Rather, T.R., Razdan, V.K., Tewari, A.K., Shanaz, E., Bhat, Z.A., Hassan, M.G. and Wani, T.A. 2012. Integrated Management of Wilt complex Disease in Bell Pepper (Capsicum annuиm L.). J. Agric. Sci. 4(7):141.

Rini, C. R. and Sulochana, K. K. 2006. Management of Seedling rot of Chilli
(Capsicum annuum L.) using Trichoderma sp. and flourecent Pseudomonas. J. Tropic. Agric. 44(1-2): 79-82.

Sawant, I.S. and Mukhopadhay, A.N. 1990. Integration of Metaxyl with Trichoderma harzianum for the control of Pythium Damping-off in Sugar beet. Indian Phytopath. 43: 535-541.

Varma, S., Kumhar, D.K., Priyanka and Sheshma, M.K. 2019. Efficacy of Bioagents and Fungicide against Root rot of Chilli caused by Rhizoctonia solani Kuhn. International Journal of Chemical Studies. 7(1): 1933-1936.

\section{How to cite this article:}

Sunaina Varma, Data Ram Kumhar, Ashok Kumar Meena, Priyanka and Balvinder. 2020. Integrated Disease Management of Rhizoctonia Root Rot of Chilli (Capsicum annum L.) Incited by Rhizoctonia solani Kuhn In Vivo. Int.J.Curr.Microbiol.App.Sci. 9(04): 1635-1642. doi: https://doi.org/10.20546/ijcmas.2020.904.192 